\title{
Antiobesity and antihypercholesterolemic effects of white tea (Camellia sinensis) infusion on high-fat diet induced obese rats
}

\section{Antiobesitas dan antihiperkolesterolemia seduhan white tea (Camellia sinensis) pada tikus yang diberi diet lemak tinggi}

\author{
Shaum Shiyan*, Herlina, Mutiara Bella, Annisa Amriani \\ Program Studi Farmasi, Fakultas Matematika dan Ilmu Pengetahuan Alam \\ Universitas Sriwijaya, Indralaya, Sumatera Selatan, Indonesia
}

Submitted: 09-06-2017

Reviewed: 12-06-2017

Accepted: 21-08-2017

\begin{abstract}
ABSTRAK
Kondisi obesitas dapat menyebabkan metabolime lipid terganggu sehingga menjadi faktor resiko hiperkolesterolemia. Katekin dan epigallocatechin gallate dalam white tea berpotensi sebagai penghambat aktivitas enzim lipase. Senyawa kafein dan derivat katekin memiliki peran sebagai antihiperkolesterolemia. Penelitian ini bertujuan untuk melihat efek antiobesitas dan antihiperkolesterolemia dari seduhan white tea terhadap kadar lipase serum serta kolesterol total serum pada tikus yang diberi diet lemak tinggi. Tikus dibagi menjadi 5 kelompok yaitu kelompok kontrol negatif yang diberi air suling, kelompok kontrol positif yang diberi orlistat dosis $14,2 \mathrm{mg} / \mathrm{kgBB}$, dan kelompok seduhan white tea dengan dosis per hari yang diberikan masing-masing yaitu 125, 250 dan $500 \mathrm{mg} / \mathrm{kgBB}$. Pakan diet lemak tinggi diberikan selama 50 hari untuk menginduksi obesitas pada semua kelompok. Parameter yang diukur meliputi kadar lipase serum dan kadar kolesterol total serum yang diukur sebelum maupun setelah pemberian diet lemak tinggi dan setelah pemberian perlakuan. Berat badan dihitung setiap 5 hari sekali selama masa perlakuan dan asupan pakan dihitung setiap hari selama perlakuan. Seduhan white tea dosis $500 \mathrm{mg} / \mathrm{kgBB}$ dapat menurunkan kolesterol total serum

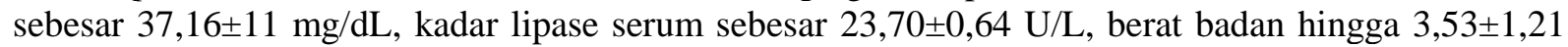
$\mathrm{g} /$ hari dan menurunkan asupan pakan sebesar 12,71 $\pm 1,76 \mathrm{~g} /$ hari. Seduhan white tea dapat menurunkan kadar kolesterol total, kadar lipase serum, berat badan dan asupan pakan. Kesimpulan dari penelitian ini bahwa seduhan white tea memiliki efek antiobesitas dan antihiperkolesterolemia pada tikus yang diberi diet lemak tinggi.
\end{abstract}

Kata kunci: white tea, antiobesitas, antihiperkolesterolemia, diet lemak tinggi, kolesterol total, lipase

\begin{abstract}
Obesity may cause the lipid metabolisms disorder so that a risk factor for hypercholesterolemic. Catechin and epigallocatechin gallate in white tea potentially inhibit lipase activity. Caffeine compounds and catechin derivatives have a role as antihypercholesterolemic. The objective of this study was to explore antiobesity and antihypercholesterolemic activity from white tea infusions to lipase and total cholesterol in rats model fed a high-fat-diet. Twenty-five rats were divided into five groups. Negative control group was administered with distilled water.
\end{abstract}

Penulis korespondesi:

Shaum Shiyan

Program Studi Farmasi, Fakultas Matematika dan Ilmu Pengetahuan Alam, Universitas Sriwijaya

Jl. Palembang-Prabumulih Km 32, Indralaya, Sumatera Selatan, Indonesia

Email: shaumshiyan@unsri.ac.id 
The positive control group was administered with orlistat dose $14.2 \mathrm{mg} / \mathrm{kgBW}$. Group $3^{\text {rd }}, 4^{\text {th }}$, and $5^{\text {th }}$ were treated with white tea infussion doses of 125,250 and $500 \mathrm{mg} / \mathrm{kgBW} / \mathrm{day}$, respectivelly. period and feed intake was calculated daily during the treatment. White tea doses of $500 \mathrm{mg} / \mathrm{kgBW}$ decrease the total cholesterol by $37.16 \pm 11 \mathrm{mg} / \mathrm{dL}$, lipase level of $23.70 \pm 0.64 \mathrm{U} / \mathrm{L}$, weight up to $3.53 \pm 1.21 \mathrm{~g} / \mathrm{day}$ and decrease feed intake by $12.71 \pm 1.76 \mathrm{~g} /$ day. The infusion of white tea can decrease total cholesterol level, lipase level, body weight and feed intake. This study concluded that infusion of white tea has antiobesity and antihypercholesterolemic effect on rats fed high-fat-diet.

Keywords: white tea, antiobesity, antihypercholesterolemic, high-fat diet, total cholesterol, lipase

\section{PENDAHULUAN}

Obesitas didefinisikan sebagai adanya lemak dalam tubuh dalam jumlah abnormal, yang mengakibatkan kegemukan pada keadaan tinggi badan dan jumlah otot tertentu. Obesitas terjadi karena penyimpanan energi dalam sel lemak yang meningkat dan menyebabkan bertambahnya jumlah serta ukuran sel lemak (Diepvens et al., 2007; Mopuri et al., 2015; Rains et al., 2011). Obesitas menyebabkan metabolime lipid terganggu sehingga menjadi faktor resiko penyakit diabetes, kanker, hipertensi, dan hiperkolesterolemia (Gutiérrez-Salmerón et al., 2017; Nakazono et al., 2016). Hiperkolesterolemia ditandai dengan meningkatnya kadar kolesterol total dalam darah dan kolesterol low density lipoprotein (LDL), kondisi ini dapat memicu terjadinya aterosklerosis maupun penyakit kardiovaskuler (Anandhi et al., 2013; Lee et al., 2010; Zárate et al., 2016).

Kondisi obesitas dapat menyebabkan terjadinya kelainan metabolisme lipid yang ditandai dengan kelainan profil lipid dalam plasma seperti kadar kolesterol total yang tinggi, kadar trigliserida yang tinggi, dan kadar kolesterol highdensity lipoprotein (HDL) yang rendah. Absorpsi asam lemak dalam tubuh sebagai langkah awal dalam metabolisme lipid dapat diturunkan dengan menghambat aktivitas enzim lipase pankreas sebagai target antiobesitas (Maqsood et al., 2017; Nomura and Casida, 2016). Kondisi hiperkolesterolemia tentunya akan membaik ketika metabolisme lipid dalam tubuh kembali normal.

Salah satu tanaman yang memiliki potensi sebagai antiobesitas dan antihiperkolesterolemia adalah teh. Berbeda dari jenis teh lainnya, white tea merupakan jenis teh yang paling banyak mengandung polifenol yakni sebesar 21,54\% b/b (Yang and Wang, 2011). White tea terbuat dari helaian pucuk dan daun pertama dengan proses pengeringan minimal tanpa mengalami proses oksidasi (Hilal and Engelhardt, 2007; Rohdiana, 2015). Senyawa katekin dan kafein dapat digunakan sebagai penurun kelebihan berat badan. Kafein bekerja sebagai antiobesitas dengan menstimulasi sistem saraf pusat simpatis yang dapat menekan rasa lapar dan memperlambat rasa kenyang sehingga terjadi penekanan pada asupan makanan (Belza et al., 2007; Diepvens et al., 2007; Hursel and WesterterpPlantenga, 2013; Westerterp-Plantenga, 2010). Senyawa dalam white tea seperti derivat flavan-3-ol, katekin, epigallocatechin gallate (EGCG), dan strictinin sebagian besar golongan fenolik berpotensi sebagai inhibitor enzim lipase (Gondoin et al., 2010; Rahim et al., 2015). Senyawa EGCG dapat menghambat enzim lipase dengan nilai $\mathrm{IC}_{50}$ sebesar $7,5 \mu \mathrm{mol} / \mathrm{L}$ yang diuji secara in vitro (Grove et al., 2012). Katekin bekerja sebagai antihiperkolesterolemia dengan proses mengikat kolesterol atau asam empedu dan menghambat penyerapan di usus (Matsui et al., 2006).

Eksplorasi terkait fitokimia, aktivitas biologis dan farmakologis dari daun teh sudah banyak dilaporkan. Akan tetapi informasi terkait antiobesitas melalui penghambatan enzim lipase dari produk white tea masih belum ada. Hasil penelitian yang ada terbatas pada black tea, oolong tea dan green tea (Fei et al., 2014; Glisan et al., 2017; Rains et al., 2011). Oleh karena itu, penelitian ini bertujuan untuk mengetahui efek antiobesitas dan antihiperkolesterolemia pemberian seduhan white tea terhadap aktivitas enzim lipase pada tikus yang diberi diet lemak tinggi. Hasil penelitian ini dapat digunakanan dalam pengembangan dan pengobatan tradisional. Selain itu dapat digunakan sebagai bahan dalam pengembangan nutraseutikal antiobesitas dan antihiperkolesterolemia. 


\section{METODE PENELITIAN \\ Hewan uji}

Hewan uji yang digunakan adalah tikus jantan galur Wistar yang berumur 2-3 bulan dengan bobot 150-250 g diperoleh dari Laboratorium Farmakologi, Program Studi Farmasi, Universitas Sriwijaya. Sertifikat etika penggunaan hewan uji diperoleh dari Unit Bioetika dan Humaniora Fakultas Kedokteran, Universitas Sriwijaya (Ethical approvel certificate No. 527/kepkrsmhfkunsri/2017).

\section{Preparasi Seduhan White Tea}

White tea dari jenis Camellia sinensis diperoleh dari Pusat Penelitian Teh dan Kina (PPTK) Gambung, Kabupaten Bandung. Proses penyeduhan mengikuti prosedur yang sudah ada dengan sedikit modifikasi menggunakan air suling pada suhu $95^{\circ} \mathrm{C}$ selama 9 menit (Braud et al., 2015; Damiani et al., 2014; Hajiaghaalipour et al., 2016).

\section{Profil Kromatografi Lapis Tipis (KLT)}

Identifikasi senyawa polifenol dalam seduhan white tea dilakukan dengan uji kualitatif menggunakan kromatografi lapis tipis. Fase gerak yang digunakan asam formiat : metanol (94:6). Pemeriksaan golongan senyawa di bawah sinar lampu UV $366 \mathrm{~nm}$ dan $254 \mathrm{~nm}$. Identifikasi diperjelas dengan pereaksi semprot $\mathrm{FeCl}_{3} 1 \%$. Hasil positif polifenol jika bercak berwarna hijau hingga biru kehitaman.

\section{Pengkondisian dan pengelompokan hewan uji}

Selama aklimatisasi tikus diberi pakan standar dan minum air ad libitium (Ramírez dkk., 2017). Pengamatan dilakukan setiap hari terhadap sisa pakan dan berat badan tikus tiap 5 hari sekali. Tikus dibagi dalam lima kelompok, terdiri dari kontrol negatif, positif dan tiga variasi dosis (Tabel I). Pakan diet lemak tinggi dibuat dengan cara mencampurkan pakan standar $200 \mathrm{~g}$ dengan kuning telur $8 \mathrm{~g}$, minyak babi $20 \mathrm{~g}$, gula $80 \mathrm{~g}$, tepung terigu $100 \mathrm{~g}$, dan minyak jagung $5 \mathrm{~mL}$ (Tsalissavrina et al., 2013).

\section{Tabel I. Pengelompokan hewan uji berdasarkan perlakuan masing-masing}

\begin{tabular}{ll}
\hline \multicolumn{1}{c}{ Kelompok } & \multicolumn{1}{c}{ Perlakuan } \\
\hline Kontrol Negatif & pakan diet lemak tinggi + air suling ad libitium \\
Kontrol Positif & pakan diet lemak tinggi + orlistat $14,2 \mathrm{mg} / \mathrm{kgBB}$ (Xenical) \\
Perlakuan 1 & pakan diet lemak tinggi + seduhan white tea $125 \mathrm{mg} / \mathrm{kgBB}$ \\
Perlakuan 2 & pakan diet lemak tinggi + seduhan white tea $250 \mathrm{mg} / \mathrm{kgBB}$ \\
Perlakuan 3 & pakan diet lemak tinggi + seduhan white tea $500 \mathrm{mg} / \mathrm{kgBB}$ \\
\hline
\end{tabular}

\section{Prosedur pengujian antiobesitas}

Pengukuran kadar kolesterol total serum dan lipase serum sebagai kontrol normal dilakukan pada hari terakhir aklimatisasi. Tikus diberi pakan diet lemak tinggi selama 50 hari hingga mengalami obesitas. Tikus dikatakan obesitas ketika berat badan bertambah sebesar $20 \%$ dari berat badan awal (Yuniarto et al., 2015). Kadar kolesterol total serum dan lipase serum kembali diukur setelah pemberian diet lemak tinggi. Tikus diberi perlakuan selama 15 hari sesuai Tabel I. Hari terakhir perlakuan dilakukan pengukuran kadar kolesterol total serum dan lipase serum. Selama perlakuan dilakukan perhitungan berat badan tikus tiap 5 hari sekali dan rerata konsumsi pakan setiap hari.

\section{Evaluasi pengukuran kadar kolesterol total}

Pengukuran kadar kolestrol total serum menggunakan metode enzimatik cholesterol oxidasepara amino antipyrine (CHOD-PAP) dengan instrumen spektrofotometri (fotometer DTN-410-K). Sejumlah $10 \mu \mathrm{L}$ serum uji ditambahkan $1000 \mu \mathrm{L}$ larutan kit kolesterol total (Diasys). Sampel diinkubasi pada suhu $25^{\circ} \mathrm{C}$ selama 10 menit. Absorbansi diukur pada panjang gelombang $500 \mathrm{~nm}$. 
Evaluasi pengukuran kadar serum lipase

Aktivitas enzim lipase diukur mengikuti protokol lipase activity colorimetric assay kit (BioVision, K722-100). Lipase menghidrolisis substrat trigliserida untuk membentuk gliserol yang diukur secara enzimatik melalui absorbansi pada panjang gelombang maksimal $570 \mathrm{~nm}$.

\section{Evaluasi Average Daily Intake dan Average Daily Gain}

Penetapan nilai average daily intake (ADI) dapat dilakukan dengan cara menghitung bobot pakan yang dikonsumsi tikus tiap hari selama masa perlakuan.
$\mathrm{ADI}=(\mathrm{Da}-\mathrm{Db}) / \mathrm{D}$
$\mathrm{Da} \quad$ : selisih antar berat pakan yang tersisa di wadah makanan $(\mathrm{g})$
$\mathrm{Db} \quad$ : jumlah sisa pakan sebelumnya $(\mathrm{g})$
D : lamanya masa perlakuan (hari)

Penetapan nilai average daily gain (ADG) dapat dilakukan dengan cara menghitung berat badan tikus tiap 5 hari sekali selama masa perlakuan.

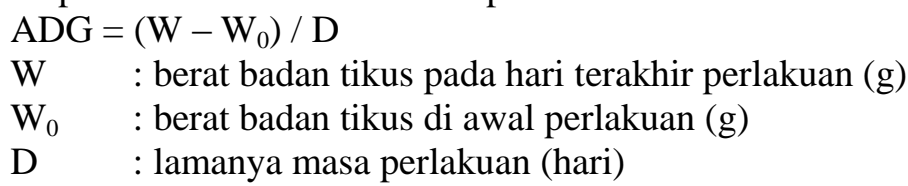

\section{Analisis Data}

Pengujian normalitas kadar lipase serum, kolesterol total serum, berat badan dan konsumsi pakan dilakukan dengan analisis shapiro-wilk. Analisis dilanjutkan dengan uji one way anova dan dilanjutkan paired simple t-test untuk melihat perbedaan antar kelompok uji dan perbedaan antara kelompok sebelum dan sesudah perlakuan dengan taraf kepercayaan $95 \%$.

\section{HASIL DAN PEMBAHASAN}

\section{Identifikasi senyawa polifenol dalam seduhan White Tea}

Menurut Rohdiana et al., (2013), white tea yang diseduh pada suhu $95^{\circ} \mathrm{C}$ selama 9 menit memiliki kandungan polifenol tertinggi. Seduhan white tea teridentifikasi memiliki senyawa polifenol pada profil kromatografi lapis tipis (Tabel II dan Gambar 1). Kromatografi lapis tipis digunakan dalam identifikasi karena mudah dilakukan dengan reagen yang sensitif dan selektif (Sugihartini et al., 2012). Identifikasi dilakukan untuk memastikan keberadaan senyawa polifenol yang akan berperan penting sebagai antiobesitas dan antihiperkolesterolemia. Polifenol utama white tea adalah katekin dan derivatnya, meliputi epicatechin (EC), epigallocatechin (EGC), epicatechin gallate (ECG), gallocatechin (GC), gallocatechin gallate (GCG) dan epigallocatechin gallate (EGCG) (Dias et al., 2013; Hu et al., 2016; Tounekti et al., 2013).

Tabel II. Identifikasi senyawa polifenol seduhan white tea menggunakan kromatografi lapis tipis

\begin{tabular}{cccc}
\hline Metabolite sekunder & UV 254 & UV 366 & FeCl $\mathbf{3}_{\mathbf{1}} \mathbf{3}$ \\
\hline Polifenol & Peredaman & Merah muda - Jingga & Biru kehitaman \\
\hline
\end{tabular}

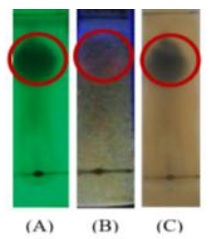

Gambar 1. Hasil pengamatan polifenol seduhan white tea pada kromatografi lapis tipis, (A) di bawah lampu UV $254 \mathrm{~nm}$, (B) UV $366 \mathrm{~nm}$, dan (C) penampak bercak $\mathrm{FeCl}_{3} 1 \%$. 


\section{Kadar kolesterol total}

Setelah 7 hari adaptasi kadar kolesterol total rata-rata semua tikus berkisar 70,63-81,66 mg/dL. Setelah pemberian pakan diet lemak tinggi selama 50 hari, terjadi kenaikan kadar kolesterol total semua tikus. Kenaikan kadar kolesterol total dalam darah disebabkan komposisi dari formulasi pakan. Minyak babi dan kuning telur merupakan sumber kolesterol dan lemak sehingga komposisi tersebut dapat meningkatkan kadar kolesterol total. Metabolisme glukosa menghasilkan asetil-KoA dan masuk ke dalam siklus asam sitrat menghasilkan energi. Menurut Murray et al., (2006) ketika energi tercukupi, asetil-KoA mengalami lipogenesis membentuk asam lemak dan disimpan sebagai trigliserida. Asetil-KoA juga dapat mengalami kolesterogenesis menjadi kolesterol. Penambahan minyak jagung dapat meningkatkan terjadinya resistensi insulin. Resistensi insulin menurunkan aktifitas enzim lipoprotein lipase, sehingga clearance dari very low density lipoprotein (VLDL) menurun akibatnya kadar VLDL dalam darah meningkat. Resistensi insulin juga dapat meningkatkan hidrolisis trigliserida, sehingga terjadi peningkatan asam lemak bebas yang akan masuk ke dalam sirkulasi darah dan menuju ke hati. Peningkatan asam lemak bebas di hati dapat merangsang sekresi dari VLDL (Coelho et al., 2013; Galic et al., 2010).

Setelah masa perlakuan terjadi penurunan kadar kolesterol total pada kelompok kontrol positif dan semua dosis seduhan white tea (Gambar 2 dan Tabel III). Terdapat perbedaan yang signifikan sebelum dan setelah tikus diinduksi pakan diet lemak tinggi $(\mathrm{p}<0,05)$. Penurunan kolesterol total tertinggi terjadi pada kontrol positif sebesar $37,163 \pm 11 \mathrm{mg} / \mathrm{dL}$. Orlistat dapat menghambat absorbsi lemak melalui penghambatan enzim lipase pankreas sehingga meningkatkan ekskresi lemak lewat feses. Sedangkan kelompok kontrol negatif tidak mengalami penurunan kadar kolesterol total melainkan terjadi peningkatan sebesar $4,19 \pm 6,98 \mathrm{mg} / \mathrm{dL}$.

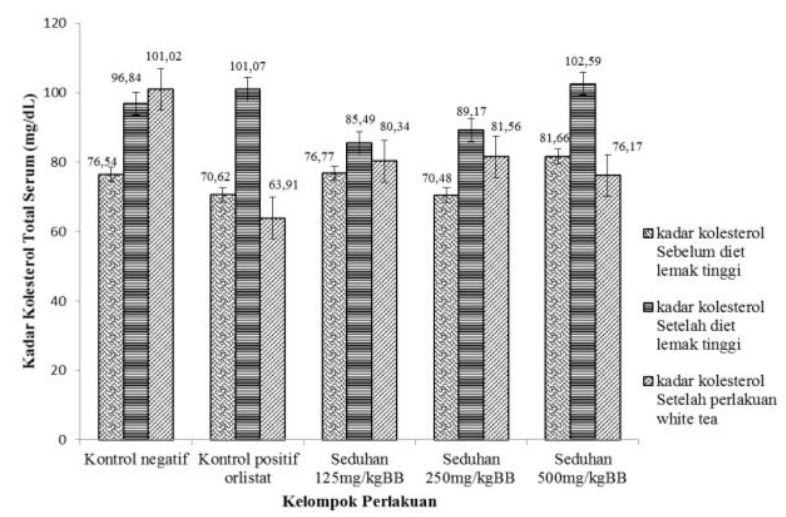

Gambar 2. Kadar kolesterol total serum sebelum dan sesudah induksi diet lemak tinggi, dan perlakuan seduhan white tea

Tabel III. Kadar kolesterol total serum setelah pemberian pakan diet lemak tinggi dan setelah perlakuan seduhan white tea

\begin{tabular}{lccc}
\hline Kelompok Perlakuan & \multicolumn{3}{c}{ Kadar Kolesterol Total (mg/dL) } \\
\cline { 2 - 4 } & $\begin{array}{c}\text { Setelah Pemberian } \\
\text { Diet Lemak Tinggi }\end{array}$ & $\begin{array}{c}\text { Setelah pemberian } \\
\text { Perlakuan }\end{array}$ & Penurunan \pm SD \\
\hline Kontrol Positif Orlistat & 101,07 & 64,00 & $37,16 \pm 11,00$ \\
Kontrol Negatif & 96,84 & 101,03 & $-4,19 \pm 6,98^{*}$ \\
White tea $125 \mathrm{mg} / \mathrm{kgBB}$ & 85,49 & 80,35 & $5,14 \pm 1,72$ \\
White tea $250 \mathrm{mg} / \mathrm{kgBB}$ & 89,17 & 81,57 & $7,61 \pm 5,79$ \\
White tea $500 \mathrm{mg} / \mathrm{kgBB}$ & 102,59 & 76,17 & $26,42 \pm 5,61$ \\
\hline
\end{tabular}

*) mengalami peningkatan kadar kolesterol total 
Pemberian seduhan white tea $500 \mathrm{mg} / \mathrm{kgBB}$ menurunkan kolesterol total lebih besar dibandingkan dosis lainnya. Hal ini kemungkinan disebabkan karena senyawa katekin dan derivatnya dapat menurunkan kadar kolesterol melalui ekspresi reseptor LDL, aktivitas faktor transkripsi SERBP1 dan melalui reseptor timbal balik kolesterol intraseluler. Absorpsi kolesterol dapat dihambat dengan mempengaruhi proses hidrolisis lipid dan pembentukan misel sehingga katekin dapat menghalangi aktivitas enzim lipase. Katekin meningkatkan konversi kolesterol menjadi asam empedu sehingga kolesterol di hati menurun (Glisan et al., 2017; Koo and Noh, 2007; Kuhn et al., 2004; Rains et al., 2011).

Menurut Kao et al., (2000), senyawa EGCG dapat menghambat aktivitas asetil Ko-A karboksilase dalam siklus biosintesa asam lemak sehingga dapat menurunkan akumulasi trigliserida pada jaringan lemak. Polifenol dapat menurunkan absorpsi kolesterol dengan cara berikatan pada kolesterol carriers saat melewati membran bruch border menghambat absorpsi kolesterol di usus. Selain itu juga meningkatkan reaksi pembentukan asam empedu dari kolesterol yang kemudian akan diekskresikan melalui feses (Yokozawa et al., 2002). Senyawa polifenol juga dapat menurunkan kadar kolesterol total dengan cara penurunan sekresi apoB yang menyebabkan penurunan produksi lipoprotein (Zern and Fernandez, 2005).

\section{Kadar lipase serum}

Setelah pemberian pakan diet lemak tinggi selama 50 hari, terjadi kenaikan kadar lipase pada rentang 24,54-58,38 U/L (Gambar 3 dan Tabel IV). Kenaikan kadar lipase serum dapat disebabkan karena adanya kandungan lemak dan minyak jagung yang tinggi dalam komposisi pakan sebagai substrat penghasil enzim lipase di dalam tubuh. Lipase pankreas menghidrolisis trigliserida dalam usus menjadi monogliserida dan asam lemak rantai panjang. Peningkatan aktivitas enzim lipase pankreas menyebabkan penyerapan monogliserida dan asam lemak meningkat.

Selama 15 hari perlakuan nilai rata-rata penurunan kadar lipase serum kelompok kontrol positif lebih besar dari pada kontrol negatif sebesar 36,15 $\pm 29,71$ U/L. Orlistat bekerja dengan cara menghambat absorbsi lemak melalui penghambatan enzim lipase pankreas sehingga meningkatkan ekskresi lemak lewat feses. Berdasarkan mekanisme tersebut, orlistat pada kelompok kontrol positif mampu menurunkan kadar lipase serum. Sedangkan kontrol negatif tidak mengalami penurunan kadar lipase serum melainkan terjadi peningkatan sebesar 2,63 $\pm 8,40 \mathrm{U} / \mathrm{L}$ (Tabel IV). Terdapat perbedaan yang signifikan terhadap penurunan aktivitas enzim lipase sebelum dan setelah induksi pakan diet lemak tinggi $(\mathrm{p}<0,05)$. Kadar lipase serum seduhan white tea 250 dan $500 \mathrm{mg} / \mathrm{kgBB}$ menunjukkan adanya perbedaan yang signifikan sebelum dan setelah perlakuan $(\mathrm{p}<0,05)$.

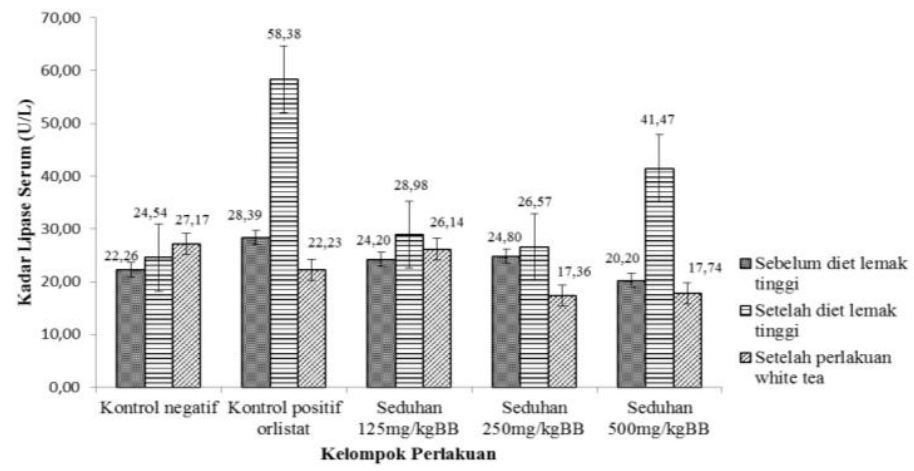

\section{Gambar 3. Kadar lipase serum sebelum dan sesudah diberi diet lemak tinggi, dan perlakuan seduhan white tea}

Penurunan kadar lipase serum kelompok kontrol positif lebih besar dari pada semua kelompok perlakuan, akan tetapi kelompok seduhan white tea $500 \mathrm{mg} / \mathrm{kgBB}$ mengalami penurunan kadar lipase serum lebih besar dibandingkan dengan dosis lain (Tabel IV). Berdasarkan hasil penelitian Hilal dan Engelhardt (2007), kandungan alkaloid dalam white tea jumlahnya relatif sedikit sebesar $4,85 \% \mathrm{~b} / \mathrm{b}$ 
dari simplisia kering. Hasil penelitian Ruiz et al., (2006) menyatakan bahwa alkaloid mampu menghambat aktivitas enzim lipase.

Tabel IV. Kadar lipase serum setelah pemberian pakan diet lemak tinggi dan setelah perlakuan seduhan white tea

\begin{tabular}{lccc}
\hline Kelompok Perlakuan & \multicolumn{3}{c}{ Kadar Lipase Serum (U/L) } \\
\cline { 2 - 4 } & $\begin{array}{c}\text { Setelah Induksi } \\
\text { Diet Lemak Tinggi }\end{array}$ & $\begin{array}{c}\text { Setelah } \\
\text { Perlakuan }\end{array}$ & Penurunan \pm SD \\
\hline Kontrol Positif Orlistat & 58,38 & 22,23 & $36,15 \pm 29,71$ \\
Kontrol Negatif & 24,54 & 27,17 & $-2,63 \pm 8,40^{*}$ \\
White tea $125 \mathrm{mg} / \mathrm{kgBB}$ & 28,98 & 26,14 & $2,84 \pm 6,86$ \\
White tea $250 \mathrm{mg} / \mathrm{kgBB}$ & 26,57 & 17,36 & $9,21 \pm 0,32$ \\
White tea $500 \mathrm{mg} / \mathrm{kgBB}$ & 41,44 & 17,74 & $23,70 \pm 0,64$ \\
\hline
\end{tabular}

*) mengalami peningkatan kadar lipase serum

\section{Perkembangan berat badan}

Pengamatan terhadap perkembangan berat badan hewan uji dilakukan selama 72 hari dan diukur setiap 5 hari sekali (Gambar 4). Berat badan konstan tikus berkisar 200-250 g. Berat badan tikus mengalami kenaikan pada hari ke 40-50. Peningkatan berat badan terjadi akibat bertambahnya jumlah lemak yang terdeposit pada jaringan adiposa. Penimbunan lemak terutama berada di bawah kulit dan rongga perut. Lemak yang tersimpan dalam jaringan adiposa pada umumnya dalam bentuk trigliserida (Basu et al., 2010; Widyaningsih and Salamah, 2015).

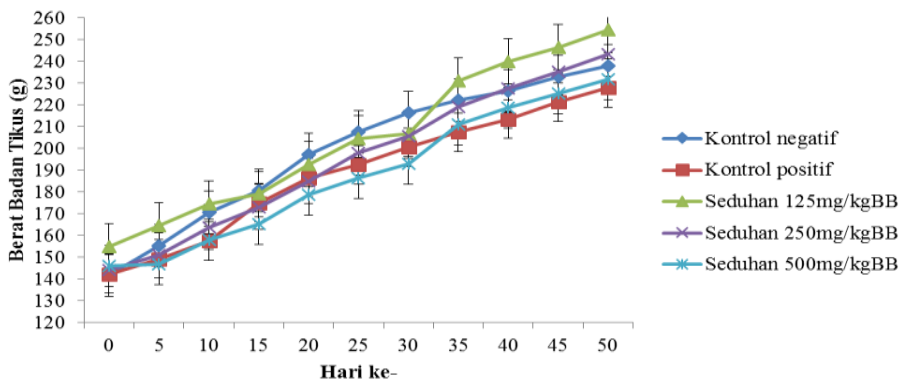

\section{Gambar 4. Perkembangan berat badan tikus selama pemberian pakan diet lemak tinggi}

Terdapat perbedaan berat badan tikus sebelum dan setelah perlakuan pada kelompok kontrol positif, seduhan white tea 250 dan $500 \mathrm{mg} / \mathrm{kgBB}(\mathrm{p}<0,05)$. Setelah perlakuan selama 15 hari kontrol positif mengalami penurunan berat badan dengan ADG sebesar 2,63 $\pm 0,32 \mathrm{~g}$. Pemberian seduhan white tea 500 dan $250 \mathrm{mg} / \mathrm{kgBB}$ menurunkan berat badan dengan parameter ADG sebesar 3,53 $\pm 1,21 \mathrm{~g}$ dan 3,36 $\pm 0,88$ g (Tabel V). Senyawa EGCG dapat menstimulasi metabolisme lemak tubuh. Senyawa EGCG dan kafein akan memicu penurunan berat badan dengan cara peningkatan oksidasi lemak tubuh (Nagao et al., 2005). Kafein dalam teh juga dapat memberikan pengaruh penurunan berat badan (Hursel and Westerterp-Plantenga, 2013).

\section{Perkembangan asupan pakan}

Perkembangan asupan pakan tikus disajikan pada Tabel V. Niai ADI dalam penelitian ini merupakan pertambahan sisi pakan per hari. Seduhan white $500 \mathrm{mg} / \mathrm{kgBB}$ mengalami pertambahan sisa pakan terbesar dari dosis seduhan lain. Senyawa EGCG dalam white tea menyebabkan peningkatan lipolisis, serta terhambatnya absorpsi makanan sehingga tikus akan merasa kenyang (Belza et al., 2007). Derivat katekin EGCG dan kafein menstimulasi sistem saraf pusat simpatis yang dapat menekan rasa lapar, memperlambat rasa kenyang, dan menstimulasi pembakaran sehingga terjadi penekanan pada asupan makanan (Diepvens et al., 2007). 
Tabel V. Rata-rata pertambahan berat badan perhari (ADG) dan asupan pakan (ADI)

\begin{tabular}{lcccc}
\hline Kelompok Perlakuan & \multicolumn{2}{c}{ Nilai ADG $(\mathbf{g})$} & \multicolumn{2}{c}{ Nilai ADI (g/hari) } \\
\cline { 2 - 5 } & $\begin{array}{c}\text { Setelah Induksi } \\
\text { Diet Lemak } \\
\text { Tinggi* }\end{array}$ & $\begin{array}{c}\text { Setelah } \\
\text { Pemberian } \\
\text { White Tea* }\end{array}$ & $\begin{array}{c}\text { Setelah Induksi } \\
\text { Diet Lemak } \\
\text { Tinggi* }\end{array}$ & $\begin{array}{c}\text { Setelah } \\
\text { Pemberian } \\
\text { White Tea }\end{array}$ \\
\hline Kontrol Positif Orlistat & $1,85 \pm 0,24$ & $-2,63 \pm 0,32^{* *}$ & $10,04 \pm 3,04$ & $12,09 \pm 2,05$ \\
Kontrol Negatif & $0,15 \pm 0,26$ & $0,18 \pm 2,17$ & $10,66 \pm 2,64$ & $11,71 \pm 1,63$ \\
White tea $125 \mathrm{mg} / \mathrm{kgBB}$ & $0,12 \pm 0,40$ & $-1,08 \pm 0,93 * *$ & $10,05 \pm 3,30$ & $10,09 \pm 11,62$ \\
White tea $250 \mathrm{mg} / \mathrm{kgBB}$ & $0,18 \pm 0,48$ & $-3,36 \pm 0,88^{* *}$ & $10,85 \pm 2,07$ & $11,83 \pm 1,53$ \\
White tea $500 \mathrm{mg} / \mathrm{kgBB}$ & $0,20 \pm 0,41$ & $-3,53 \pm 1,21^{* *}$ & $10,75 \pm 2,28$ & $12,714 \pm 1,76$ \\
\hline
\end{tabular}

*) $\pm \mathrm{SD}$;*) terjadi penurunan berat badan

Adanya perbedaan rata-rata konsumsi hewan uji antar kelompok dapat disebabkan faktor jenis pakan seperti tekstur, ukuran dan konsistensi pakan yang tidak jauh berbeda antara pakan diet lemak tinggi dan pakan standar sehingga memberikan respon tingkat kesukaan yang sama pada setiap hewan coba. Selain itu menurut Abidah et al., (2013), faktor jenis pakan, variasi biologis, dan pemberian pakan yang sama banyak dapat mempengaruhi tingkat konsumsi pakan hewan uji. Seduhan white tea $125 \mathrm{mg} / \mathrm{kgBB}$ menunjukkan adanya perbedaan rata-rata konsumsi pakan tikus perharinya selama pemberian pakan dan selama perlakuan $(\mathrm{p}<0,05)$.

\section{KESIMPULAN}

Pemberian seduhan white tea dapat menurunkan kolesterol total serum dan kadar lipase serum tikus yang diberi pakan diet lemak tinggi. Seduhan white tea mampu menurunkan berat badan tikus dan asupan pakan. Seduhan white tea dapat digunakan dalam pengobatan tradisional sebagai antiobesitas dan antihiperkolesterolemia. Produk white tea dapat dikembangkan sebagai bahan nutraseutikal antiobesitas dan antihiperkolesterolemia.

\section{UCAPAN TERIMAKASIH}

Terima kasih kepada Laboratorium Biologi Farmasi Dan Farmakologi, Program Studi Farmasi, Fakultas Matematika dan Ilmu Pengetahuan Alam, Universitas Sriwijaya, Pusat Penelitian Teh dan Kina (PPTK) Gambung dan semua pihak yang membantu terlaksananya penelitian ini.

\section{DAFTAR PUSTAKA}

Abidah, N., Widyaningsih, T.D., Nugraheni, N.I.P., Wijayanti, S.D., and Maligan, J.M., 2013. Pengaruh margarin apel manalagi tersuplementasi minyak kacang tanah terhadap kadar kolesterol tikus Sprague dawley jantan. Jurnal Pangan dan Agroindustri, 2: 18-27.

Anandhi, R., Annadurai, T., Anitha, T.S., Muralidharan, A.R., Najmunnisha, K., Nachiappan, V., et al., 2013. Antihypercholesterolemic and antioxidative effects of an extract of the oyster mushroom, Pleurotus ostreatus, and its major constituent, chrysin, in Triton WR-1339-induced hypercholesterolemic rats. Journal of Physiology and Biochemistry, 69: 313-323.

Basu, A., Sanchez, K., Leyva, M.J., Wu, M., Betts, N.M., Aston, C.E., et al., 2010. Green tea supplementation affects body weight, lipids, and lipid peroxidation in obese subjects with metabolic syndrome. Journal of the American College of Nutrition, 29: 31-40.

Belza, A., Toubro, S., and Astrup, A., 2007. The effect of caffeine, green tea and tyrosine on thermogenesis and energy intake. European Journal of Clinical Nutrition, 63: 57-64.

Braud, L., Peyre, L., de Sousa, G., Armand, M., Rahmani, R., and Maixent, J.-M., 2015. Effect of brewing duration on the antioxidant and hepatoprotective abilities of tea phenolic and alkaloid compounds in a t-BHP oxidative stress-induced rat hepatocyte model. Molecules, 20: 1498515002.

Coelho, M., Oliveira, T., and Fernandes, R., 2013. Biochemistry of adipose tissue: an endocrine organ. Archives of Medical Science: AMS, 9: 191-200. 
Damiani, E., Bacchetti, T., Padella, L., Tiano, L., and Carloni, P., 2014. Antioxidant activity of different white teas: comparison of hot and cold tea infusions. Journal of Food Composition and Analysis, 33: 59-66.

Dias, T.R., Tomás, G., Teixeira, N., Alves, M.G., Oliveira, P.F., and Silva, B.M., 2013. White tea (Camellia sinensis (1.)): antioxidant properties and beneficial health effects. International Journal of Food Science, Nutrition and Dietetics, 2: 19-26.

Diepvens, K., Westerterp, K.R., and Westerterp-Plantenga, M.S., 2007. Obesity and thermogenesis related to the consumption of caffeine, ephedrine, capsaicin, and green tea. American Journal of Physiology - Regulatory, Integrative and Comparative Physiology, 292: 77-85.

Fei, Q., Gao, Y., Zhang, X., Sun, Y., and Hu, B., 2014. Effects of oolong tea polyphenols, EGCG, and EGCG3"Me on pancreatic $\alpha$-amylase activity in vitro. Journal of Agricultural and Food Chemistry, 62: 9507-9514.

Galic, S., Oakhill, J.S., and Steinberg, G.R., 2010. Adipose tissue as an endocrine organ. Molecular and Cellular Endocrinology, Endocrine Aspects of Obesity 316: 129-139

Glisan, S.L., Grove, K.A., Yennawar, N.H., and Lambert, J.D., 2017. Inhibition of pancreatic lipase by black tea theaflavins: comparative enzymology and in silico modeling studies. Food Chemistry, 216: $296-300$.

Gondoin, A., Grussu, D., Stewart, D., and McDougall, G.J., 2010. White and green tea polyphenols inhibit pancreatic lipase in vitro. Food Research International, 43: 1537-1544.

Grove, K.A., Sae-Tan, S., Kennett, M.J., and Lambert, J.D., 2012. (-)-Epigallocatechin-3-gallate inhibits pancreatic lipase and reduces body weight gain in high fat-fed obese mice. Obesity, 20: 2311-2313.

Gutiérrez-Salmerón, M., Chocarro-Calvo, A., García-Martínez, J.M., de la Vieja, A., and GarcíaJiménez, C., 2017. Epidemiological bases and molecular mechanisms linking obesity, diabetes, and cancer. Endocrinología, Diabetes y Nutrición (English ed.), 64: 109-117.

Hajiaghaalipour, F., Sanusi, J., and Kanthimathi, M.S., 2016. Temperature and time of steeping affect the antioxidant properties of white, green, and black tea infusions. Journal of Food Science, 81: 246-254.

Hilal, Y. and Engelhardt, U., 2007. Characterisation of white tea - Comparison to green and black tea. Journal für Verbraucherschutz und Lebensmittelsicherheit, 2: 414-421.

Hu, C.J., Gao, Y., Liu, Y., Zheng, X.Q., Ye, J.H., Liang, Y.R., et al., 2016. Studies on the mechanism of efficient extraction of tea components by aqueous ethanol. Food Chemistry, 194: 312-318.

Hursel, R. and Westerterp-Plantenga, M.S., 2013. Catechin- and caffeine-rich teas for control of body weight in humans. The American Journal of Clinical Nutrition, 98: 1682-1693.

Kao, Y., Hiipakka, R.A., and Liao, S., 2000. Modulation of obesity by a green tea catechin. The American Journal of Clinical Nutrition, 72: 1232-1233.

Koo, S.I. and Noh, S.K., 2007. Green tea as inhibitor of the intestinal absorption of lipids: potential mechanism for its lipid-lowering effect. The Journal of Nutritional Biochemistry, 18: 179-183

Kuhn, D.J., Burns, A.C., Kazi, A., and Ping Dou, Q., 2004. Direct inhibition of the ubiquitinproteasome pathway by ester bond-containing green tea polyphenols is associated with increased expression of sterol regulatory element-binding protein 2 and LDL receptor Biochimica et Biophysica Acta (BBA) - Molecular and Cell Biology of Lipids, 1682: 1-10.

Lee, Y.S., Yang, J.H., Bae, M.J., Yoo, W.K., Ye, S., Xue, C.C.L., et al., 2010. Anti-oxidant and antihypercholesterolemic activities of Wasabia japonica. Evidence-based Complementary and Alternative Medicine : eCAM, 7: 459-464.

Maqsood, M., Ahmed, D., Atique, I., and Malik, W., 2017. Lipase inhibitory activity of Lagenaria siceraria fruit as a strategy to treat obesity. Asian Pacific Journal of Tropical Medicine, 10: 305-310.

Matsui, Y., Kumagai, H., and Masuda, H., 2006. Antihypercholesterolemic activity of catechin-free saponin-rich extract from green tea leaves. Food Sci. Technol. Res., 12: 50-54. 
Mopuri, R., Ganjayi, M., Banavathy, K.S., Parim, B.N., and Meriga, B., 2015. Evaluation of antiobesity activities of ethanolic extract of Terminalia paniculata bark on high fat diet-induced obese rats. BMC Complementary and Alternative Medicine, 15: 76.

Murray, R., Granner, D., and Rodwell, V., 2006. Biokimia, 27th ed. Penerbit Buku Kedokteran EGC, Jakarta, Indonesia.

Nagao, T., Komine, Y., Soga, S., Meguro, S., Hase, T., Tanaka, Y., et al., 2005. Ingestion of a tea rich in catechins leads to a reduction in body fat and malondialdehyde-modified LDL in men. The American Journal of Clinical Nutrition, 81: 122-129.

Nakazono, S., Cho, K., Isaka, S., Abu, R., Yokose, T., Murata, M., et al., 2016. Anti-obesity effects of enzymatically-digested alginate oligomer in mice model fed a high-fat-diet. Bioactive Carbohydrates and Dietary Fibre, 7: 1-8.

Nomura, D.K. and Casida, J.E., 2016. Lipases and their inhibitors in health and disease. ChemicoBiological Interactions, 12th International Meeting on Cholinesterases and 6th Conference of Paraoxonase 259: 211-222.

Rahim, A.T.M.A., Takahashi, Y., and Yamaki, K., 2015. Mode of pancreatic lipase inhibition activity in vitro by some flavonoids and non-flavonoid polyphenols. Food Research International, 75: 289-294.

Rains, T.M., Agarwal, S., and Maki, K.C., 2011. Antiobesity effects of green tea catechins: a mechanistic review. The Journal of Nutritional Biochemistry, 22: 1-7.

Ramírez, M.D., Toledo, R.C.L., Moreira, M.E.C., Martino, H.S.D., and Benjamin, L.D.A., 2017. Antiobesity effects of tea from Mangifera indica L. leaves of the Ubá variety in high-fat diet-induced obese rats. Biomedicine and Pharmacotherapy, 91: 938-945.

Rohdiana, D., 2015. Teh: proses, karakteristik dan komponen fungsionalnya. Food Review Indonesia, 10: $34-37$.

Rohdiana, D., Arief, D.Z., and Somantri, M., 2013. (1, 1-Diphenyl-2-Picrylhydrazyl) free radical scavenging activity of white tea base on temperature and period of brewing. Jurnal Penelitian Teh dan Kina, 16: 45-50.

Ruiz, C., Falcocchio, S., Xoxi, E., Villo, L., Nicolosi, G., Pastor, F.I.J., et al., 2006. Inhibition of Candida rugosa lipase by saponins, flavonoids and alkaloids. Journal of Molecular Catalysis B: Enzymatic, Synthesis, Testing and Pharmacological Applications of Inhibitors of Lipolytic Enzymes 40: 138-143.

Sugihartini, N., Fudholi, A., Pramono, S., and Sismindari, S., 2012. Validasi metode analisa penetapan kadar epigalokatekin galat dengan KLT densitometri. Pharmaciana, 2: 81-87.

Tounekti, T., Joubert, E., Hernández, I., and Munné-Bosch, S., 2013. Improving the polyphenol content of tea. Critical Reviews in Plant Sciences, 32: 192-215.

Westerterp-Plantenga, M.S., 2010. Green tea catechins, caffeine and body-weight regulation. Physiology \& Behavior, Beverages and Health 100: 42-46

Widyaningsih, W. and Salamah, N., 2015. Efek ekstrak etanol ganggang hijau (Ulva lactuca L) terhadap berat badan dan kadar trigliserida tikus jantan yang diberi diet lemak tinggi. Pharmaciana, 5: 191-198.

Yang, C.S. and Wang, H., 2011. Mechanistic issues concerning cancer prevention by tea catechins. Molecular Nutrition \& Food Research, 55: 819-831.

Yokozawa, T., Nakagawa, T., and Kitani, K., 2002. Antioxidative Activity of Green Tea Polyphenol in Cholesterol-Fed Rats. Journal of Agricultural and Food Chemistry, 50: 3549-3552.

Yuniarto, A., Kurnia, I., and Ramadhan, M., 2015. Anti-obesity effect of ethanolic extract of jasmine flowers (jasminumsambac(l)Ait) in high-fat dietinduced mice: potent inhibitor of pancreatic lipase enzyme. International Journal of Advances In Pharmacy, Biology And Chemistry, 4: 1822.

Zárate, A., Manuel-Apolinar, L., Saucedo, R., Hernández-Valencia, M., and Basurto, L., 2016. Hypercholesterolemia as a risk factor for cardiovascular disease: current controversial therapeutic management. Archives of Medical Research, 47: 491-495. 
Zern, T.L. and Fernandez, M.L., 2005. Cardioprotective effects of dietary polyphenols. The Journal of Nutrition, 135: 2291-2294. 